Article

\title{
Determinants and convergence of income diversification in Ghanaian banks
}

\author{
King Carl Tornam Duho ${ }^{1 *}$, Joseph Mensah Onumah ${ }^{2}$, and Emmanuel Tetteh Asare ${ }^{3}$ \\ 1 Department of Accounting, University of Ghana, Accra, Ghana ; IMANI Centre for Policy and Education ; \\ kctduho@gmail.com \\ 2 Department of Accounting, University of Ghana, Accra, Ghana ; Heritage Christian College, Accra, Ghana; \\ jmonumah@ug.edu.gh \\ 3 Department of Accounting, University of Ghana, Accra, Ghana ; etasare@ug.edu.gh \\ * Correspondence: kctduho@gmail.com
}

Received: 25 February 2020; Accepted: 5 April 2020; Published: 5 April 2020

\begin{abstract}
The study explores the determinants of income diversification, as well as, test for the existence of beta-convergence and sigma-convergence among Ghanaian banks. The study utilizes a dataset of 32 banks covering the periods 2000 to 2017. The panel corrected standard error ordinary least squares, fixed effects and system generalized methods of moments have been used. Both betaconvergence and sigma-convergence exist among Ghanaian banks; suggesting the presence of the catch-up effect and similarity of strategy over time. The risk profile and risk portfolio of banks affect their diversification strategy. Banks that are faced with high insolvency risk and liquidity risk tend to diversify while banks that are faced with low credit risk tend to diversify. Stable banks tend to adopt a diversification strategy even when they are exposed to credit risk. Network embeddedness drives diversification strategy. The implications of the study for practice, policy, and future research have been discussed.
\end{abstract}

Keywords: neo-classical growth theory, convergence, income diversification, risk, Bank of Ghana, Financial Stability Council.

JEL codes: G21, L2, G32

\section{Introduction}

Banks are shifting their revenue models from the traditional financial intermediation business to non-interest activities such as consulting and brokerage. In 1984 non-interest income formed 25 percent of the total income of U.S. banks but has inched up and in 2001 it formed 43 percent of the income (Stiroh, 2004). Recently, Haubrich and Young (2019) analyzed the trends in the non-interest income of banks in the U.S. from 2001 to 2018 covering the period of the global financial crisis. The results suggest that despite the low-interest rates over the period, the income from non-interest operations decreased over the period. Some sub-components of non-interest income which are linked to the global financial crisis such as securitization, trading income and real estate decreased but there has been significant growth in service charges. There are two main opposing strategies which are the focused strategy versus the diversified strategy. Depending significantly on interest income suggests a diversified strategy while dependence significantly on non-interest income also suggests a diversification strategy.

Some theories have erupted with varying predictions on whether banking activities should be restricted or not. The arguments that have existed in the extant literature are varied: diversifying income sources intensifies moral hazard problem (Boyd, Chang, \& Smith, 1998), conflicts of interests 
(John, John, \& Saunders, 1994; Saunders, 1994), and complicate the complexity in regulatory monitoring (Barth, Caprio, \& Levine, 2004). The counter assertion to these is that allowing few regulations enable banks to benefit from economies of scope (Claessens \& Klingebiel, 2001). Following these arguments, various studies have explored the impact of income diversification on profitability or risk. The results of these studies differ depending on the economies examined or the type of banks explored (Abedifar, Molyneux, \& Tarazi, 2018; Stiroh, 2004; Thota, 2019; Wild, 2016). There is still paucity in literature regarding the determinants and the convergence of bank income diversification among banks in developing economies.

The Ghanaian banking industry has witnessed various reforms in the 1980s when the Bretton Woods institutions advised the government to employ various policy suggestions which include deregulation, privatization, and liberalization. This has significantly affected the banking industry, leading to positive results as competition in the industry improved. Although there is no significant empirical finding to suggest that the 2007-8 global financial crisis affected the sector, there have been various financial sector crises that have bedeviled the industry in this 21st century. In early 2000, some banks collapsed as a result of huge non-performing loans (Duho \& Onumah, 2019). Despite reforms over the years, the non-performing loans increased leading to liquidity problems, solvency problems, efficiency weaknesses with the possibility of systemic risk that could affect the whole economy. This resulted in the capture of a financial sector clean-up in the political manifesto during the 2016 election and subsequently among key policy preferences. In 2017, the Bank of Ghana commenced a banking sector clean-up exercise which reduced the total licensed Universal banks from 34 to 23. The little knowledge in the literature as to what factors determine income diversification or that on the convergence of income diversification provides limited knowledge for policymakers, academics, and practitioners.

The current study aims to fill the dearth in literature by examining the determinants and convergence of income diversification. To achieve this, the study answers two research questions: (1) Do beta-convergence and/or sigma-convergence exist(s) among Ghanaian banks? (2) What are the determinants of income diversification among Ghanaian banks? The study utilizes banking data covering the period from 2000 to 2017 to provide the analysis. Using the convergence models based on the neoclassical growth model, the study found that both beta-convergence and sigma-convergence of income diversification exist among Ghanaian banks. The evidence of this catch-up effect suggests that less diversified banks increase their level of diversification more than the diversified banks. This is typical because the banks imitate and copy from each other in terms of technology and practices. The result indicates that banks consider their risk profile and risk portfolio in choosing between a diversified or focused strategy. Large banks tend to diversify but at some point, they tend to limit the level of diversification, especially when the risk-return trade-off does not favor them. Network embeddedness increases banks' decision to diversify as it gives them the leverage to benefit from diversification. The results are essential for bank management and policy-making, especially for the newly established Financial Stability Council.

The next section provides a critical review of income diversification and convergence literature. The third section provides a description of the methodology and methods used for the study. The fourth section presents the results of the analysis and some discussion of the results. The penultimate section concludes the study and the last section provides insightful implications of the study for policy, practice and future research.

\section{Literature Review}

\subsection{Concept of Bank Diversification}

The concept of bank diversification emerges from portfolio theory. Portfolio theory is concerned with how to minimize risks and maximize returns by spreading out investments across different asset classes. Diversification involves expanding investment activities into activities that are not perfectly correlated (Stiroh, 2007, p. 8). It involves carrying out activities that are unrelated to reduce any 
exposure from a single activity. Diversification among banks has been enhanced through the use of Universal banking license status. This status allows banks to add to their core banking mandate a range of financial services. The services include commercial banking, investment banking, and insurance among others. In diversifying activities, the focus of banks could be on the mode of asset classification or the source of income. These two give rise to two forms of diversification namely asset diversification and income diversification. To diversify bank assets means investing assets in varied asset types which could be in the form of loans and advances, underwritten securities and investment assets. In effect, much focus is placed on the statement of financial position of a bank under asset diversification. Income diversification, on the other hand, focusses on the statement of comprehensive income of banks and seeks to focus on the sources of revenue or income of banks. Banks generate income from sources such as interest income (e.g. interest on loans and advances) and non-interest income (e.g. service charges, trading income, or income from investment banking). Banks are said to be focused when they mainly generate income from interest income. Contrariwise, they are said to be income diversified when they generate more income from non-interest income sources. This study focuses on income diversification and provides the empirical review skewed more towards income diversification.

\subsection{Income Diversification Studies}

In recent times, there have been concerns among bankers, analysts, policy-makers and the academic community as to whether or not banks should diversify (DeYoung \& Rice, 2004; Hayden, Porath, \& Westernhagen, 2007; Stiroh, 2004). Banks diversify in terms of products, services, and geographical location but this review concentrates on the literature on diversification of non-interest income sources of banks. It is expected that non-interest income in the total income of banks will improve earnings. Similarly, increasing levels of non-interest income will decrease the percentage of interest income which will decrease the interest rate risk and credit risk exposure of banks. On the other hand, DeYoung and Roland (2001) argued that diversification increases the riskiness of banks as the risk reductions from diversifying to non-interest income may be undone when other risks (such as increased financial leverage) are taken. Various studies in the literature explored the bank diversification in various countries (Baele, De Jonghe, \& Vander Vennet, 2007; Chiorazzo, Milani, \& Salvini, 2008; DeYoung \& Rice, 2004; DeYoung \& Roland, 2001; Meng, Cavoli, \& Deng, 2018; Mercieca, Schaeck, \& Wolfe, 2007; Pennathur, Subrahmanyam, \& Vishwasrao, 2012; Stiroh, 2004; Stiroh \& Rumble, 2006; Thota, 2019).

In a study on 472 commercial banks in the U.S., DeYoung and Roland (2001) found evidence to suggest that increasing non-interest activities in banks results in higher earnings volatility. Similarly, DeYoung and Rice (2004) explored the nexus between non-interest income and financial performance of commercial banks in the U.S., based on the fact that non-interest income grew to form over 40 percent of total operating income (Stiroh, 2004). The result suggests that marginal increases in noninterest activities result in poor risk management. It found that the growth of non-interest income would not suggest the replacement for traditional banking activities which earns interest income. The study found that technological improvements in mutual funds and cashless transactions increase the percentage of non-interest income while technological improvements in loan securitization reduce the percentage. Another study on the U.S. banks by Stiroh (2004) found that non-interest income is more volatile relative to the interest income of banks. Specifically, trading income which forms part of the non-interest income is the main component driving the volatility. On the part of financial holding companies, the study by Stiroh and Rumble (2006) using data covering 1997 to 2002 found evidence to suggest that although the gains of diversification exist, they are offset by increased exposure to noninterest income which is relatively volatile. These results provide insights into the possible dark side of diversification in banks.

The arguments about the benefits of diversification have been extended by Mercieca et al. (2007) to the European small bank's context. Empirical results suggest that there is a negative effect of noninterest income on performance and there is no evidence of a direct benefit of diversification across and between the business lines of banks. This implies that banks diversify into business activities in 
which they have less experience and expertise. Contrariwise, Baele et al. (2007) provide evidence to suggest that bank diversification enhances the franchise value which is the present value of all future cash flows that banks are expected to earn. In effect, the revenue and cost benefits of diversification outweigh the associated agency costs and increased complexity. In another study by Chiorazzo et al. (2008), the result suggests that income diversification increases the risk-adjusted returns of banks which is in agreement with results in Europe but contrary to results in the U.S. In the Indian context, Pennathur et al. (2012) found that diversification does not increase the volatility of profitability of banks which is a measure of risk. Similarly, Thota (2019) found that revenue diversification provides beneficial outcomes among both private and public banks in India.

Although income diversification has been explored in the length and breadth of the extant literature, comparatively fewer studies explored the determinants of income diversification (Ammar \& Boughrara, 2019; Meng et al., 2018). Using a robust regression technique, Meng et al. (2018) posit that income diversification among banks portrays various levels of managerial capabilities in China. These include asset scale, capital position, ownership structure, cost, and insolvency risks. The results indicate that factors such as cost of production, equity to the asset, market share, foreign stake and banking asset to the gross domestic product have a positive effect on income diversification. On the other hand, insolvency risk, interest spread, interest rate volatility, and inflation rate are some factors that harm income diversification. Ammar and Boughrara (2019) conducted a cross-country study on bank diversification using the Middle East and North Africa (MENA) countries. The study defines functional diversification similar to income diversification. The results suggest that functional diversification across the dataset is stratified by financial intermediation and market share. Results further reveal that among banks in the Gulf Cooperation Council (GCC) countries, the main determinants of functional diversification are risk-adjusted profitability and loan loss provision. In contrast, among non-GCC banks, functional diversification is driven by market share, financial intermediation, and net interest margin ratio. The ambivalent results suggest that the effects of diversification could differ based on the industry, economy and period under examination.

\subsection{Convergence}

There is growing interested in understanding the convergence of performance in firms. The convergence literature is based on the seminal work of Barro and Sala-i-Martin (1991) which proposes the beta-convergence and sigma-convergence (see (Barro, 1991; Barro \& Sala-i-Martin, 1992)). The concepts are linked to the neoclassical growth theory of Solow (1956) which assumes diminishing returns for factors of production, particularly capital. In the context of banks, convergence theory suggests that less profitable banks grow faster than profitable banks. Although the concept has been applied in the macroeconomic context to examine the growth of economies, or regions, there are emerging studies that are examining the convergence of bank performance (Andrieş \& Căpraru, 2014). In a study on bank holding companies in the U.S., Fung (2006) found no evidence for absolute convergence but rather conditional convergence. Similarly, Casu and Girardone (2010) found evidence to suggest that the efficiency of EU banks converges towards an EU average which is due to a 'lagging' effect and not a 'catching up' effect. Similarly, Andrieş and Căpraru (2014) also found evidence to conclude that convergence of competition exists in European banking industries. Wild (2016) also found evidence of convergence of efficiency, equity to total assets and z-scores of banks in the Eurozone. This differs depending on the type of banks (i.e. commercial, savings or cooperative) and the period.

The interest in understanding the dynamics of income diversification continues to grow as banks continue to shift focus to non-traditional activities such as consulting and brokerage. The evidence provided by the extant literature fails to provide an insight into the determinants of income diversification in emerging markets especially in Africa since previous studies have focused on the U.S., Europe or Asia. Quintessentially, there is still a research gap as to whether or not income diversification of banks converges and how risk factors affect income diversification. 


\section{Data and Methods}

\subsection{Data}

This study utilizes a dataset of 37 banks forming the total population of all banks that operated during the study period 2000 to 2017. The data has been sourced from the Banking Supervision Department of the Bank of Ghana. The data represents an unbalanced panel data of 418 observations. Due to the lag effects of the variables, a total sample of 32 banks has been finally used. The selection comprises of both old and new banks irrespective of whether they have liquidated. This is to control for the possibility of survival bias.

\subsection{Convergence Model}

Earlier convergence models used by Barro and Sala-i-Martin (1991), Fung (2006) Casu and Girardone (2010), Andrieş and Căpraru (2014) and Wild (2016) have been adopted in this study to examine the existence or otherwise of both beta-convergence and sigma-convergence of income diversification among Ghanaian banks. The beta-convergence model is specified as follows:

$$
I d i v_{i, t}-\operatorname{Idiv}_{i, t-1}=\alpha_{0}+\beta_{1} \operatorname{Idiv}_{i, t-1}+\gamma_{2} \operatorname{TREND}_{t}+\varepsilon_{i, t}
$$

Where Idivi,t represents income diversification in the current year, Idivi,t-1 represents the 1-year lag income diversification, TREND represents the path of income diversification improvement for the entire industry, $\alpha$ represents the constant term and $\varepsilon$ represents the error term. $\beta$ represents the rate of convergence of income diversification. There is evidence of beta-convergence when $\beta<0$ with higher values indicating faster rates while there is evidence of beta-divergence when $\beta>0$ with a higher value indicating faster rates. Two models are computed with the first model without the time trend and the second model with the time trend.

Beta-convergence is limited because it does not provide information about the dispersion of the cross-section evolved. Also, when less diversified firms diversify faster than the more diversified counterparts, a situation will arise where there will be an absence of convergence when the former surpasses the latter. While beta-convergence tests for lagging behind process or catching-up, sigmaconvergence tests for the reduction of disparities among banks over the years. For the estimation of the sigma-convergence or cross-sectional convergence, the following regression model is specified:

$$
D_{i, t}-D_{i, t-1}=\alpha_{0}+\beta_{1} D_{i, t-1}+\gamma_{2} \operatorname{TREND}_{t}+\varepsilon_{i, t},
$$

where:

$$
D_{i, t}=I d i v_{i, t}-\operatorname{MIdiv}_{t},
$$

and Idivit, represents income diversification in the current year, MIdiv $t$ represents the average Idiv for each year, TREND represents the path of income diversification improvement for the entire industry, $\alpha$ represents the constant term and $\varepsilon$ represents the error term. $\beta$ represents the rate of convergence of income diversification. There is evidence of sigma-convergence when $\beta<0$ with higher values indicating faster rates while there is evidence of sigma-divergence when $\beta>0$ with a higher value indicating faster rates. Two models are computed with the first model without the time trend and the second model with the time trend.

\subsection{Determinants Model}

The study adopts the regression models of earlier studies such as Meng et al. (2018) and Laeven and Levine (2007) to explore the determinants of income diversification in banks. The mathematical model is represented as follows: 


$$
\text { Idiv }_{i, t}=\alpha_{0}+\beta_{1} Z-\text { score }_{i, t}+\beta_{2} C-\text { risk }_{i, t-1}+\beta_{3} \text { Liquidity }_{i, t}+\beta_{4} \text { Size }_{i, t}+\beta_{5} \text { Network }_{i, t}+\varepsilon_{i, t}
$$

Idiv represents income diversification, $z$-score is a measure of bank stability, C-risk represents credit risk which is lagged by one year, Liquidity represents the liquidity risk of banks, Size represents bank size and Network represents the network embeddedness of banks. $\alpha$ represents the constant term, $\beta_{1-5}$ represents the coefficients and $\varepsilon$ is the error term. The model is a panel regression model with data covering bank $i$ for each time $t$.

\subsection{Description of Variables}

\subsubsection{Dependent Variable}

In the extant literature, various ratios have been used to proxy the level at which banks diversify their income sources. This study uses a more robust model that has been used by Laeven and Levine (2007) which produces an index for measuring the level of diversification of banks. The ratio is specified as follows:

$$
\text { Idiv }=1-\left|\frac{\text { Net Interest Income }- \text { Other Operating Income }}{\text { Total Operating Income }}\right|
$$

Where net interest income is interest income fewer interest expenses, other operating income is fees and commission income and other types of income and total operating income are the total income from both interest and non-interest trading activities. The index ranges from 0 to 1 with a higher score signifying greater income diversification. Table I provides the subcategories of the noninterest income of banks.

Table 1. Subcategories of Noninterest Income of Banks

\begin{tabular}{|c|c|}
\hline $\begin{array}{c}\text { Category of noninterest } \\
\text { income }\end{array}$ & Components \\
\hline Service charges & $\begin{array}{c}\text { Service charges, ATM fees, income from the sales of checks, safe deposit box } \\
\text { fees, wire transfer fees, card charges }\end{array}$ \\
\hline Trade & $\begin{array}{c}\text { Trading revenue, net securitization income, net loans and leases sales, net } \\
\text { real estate sales, net other sales }\end{array}$ \\
\hline Investment banking & $\begin{array}{c}\text { Income from fiduciary activities, venture capital income, securitization fees, } \\
\text { annuity fees, insurance }\end{array}$ \\
\hline Other & Other (food stamps, rent on a property, foreign exchange profits) \\
\hline
\end{tabular}

Source: Haubrich and Young (2019)

\subsubsection{Independent Variables}

The $z$-score is used to account for risk as is used in studies such as Stiroh and Rumble (2006), Meng et al. (2018) and Duho, Onumah, and Owodo (2020). The score can be mathematically expressed as follows:

$$
z-\text { score }=\frac{R O A+\text { Equity } / \text { Assets }}{\sigma R O A}
$$

The resultant variable is a measure of the level of stability of the banks and higher values suggest a high level of stability and lower values suggest a lower level of stability of banks. It is expected that a negative relationship exists between income diversification and z-score since banks that are exposed more to volatility in income would seek to diversify into non-interest activities for potential profits. Also, credit risk is included to examine the impact on income diversification of banks in line with studies such as Abedifar et al. (2018) and Lin, Chung, Hsieh, and Wu (2012). The ratio of loan loss 
provisions to total loans is used to measure the credit risk exposure of banks. The one-year lag of the ratio is used to reflect the fact that the effect of the provision is dependent on the expectation for the preceding year. A negative relationship is envisaged between the credit risk and income diversification since less diversified banks would be exposed more to high credit risk. Moreover, the measure of liquidity risk has been included to explore the impact of liquidity stance of banks on income diversification. Liquidity ratio has been employed in studies such as Vithessonthi (2016), Zhang, Jiang, $\mathrm{Qu}$, and Wang (2013) and Lin et al. (2012). This is measured as the ratio of cash and cash equivalents to the total assets of banks. A high ratio suggests low liquidity risk and low values suggest high liquidity risk in banks. Either a negative or a positive relationship is expected between liquidity risk and income diversification among banks.

The size of banks is used to examine the impact of bank size on income diversification. The natural logarithm of total assets is used to measure the size in line with earlier studies such as Chiorazzo et al. (2008), Stiroh and Rumble (2006), Stiroh (2004) and DeYoung and Rice (2004). Large banks could have the financial and intellectual capital to develop the expertise and capability of their human capital to carry out more business lines. Contrariwise, smaller have the operational flexibility to adapt their operations to changing environments in the industry at a low cost. In effect, there is a possibility of a negative or a positive relationship between size and income diversification. To further explore the possible non-linear relationship, the square of size is included to explore the possibility (Chiorazzo et al., 2008). Network embeddedness of banks describes the various networks between activities, resources, actors, and institutions. It is expected that banks that have a good network system such as branches, technology, and human capital would have high deposits. Following earlier studies (Sufian, 2009; Sufian \& Habibullah, 2012; Sufian \& Noor, 2012), this study uses the ratio of deposits to assets as a measure of network embeddedness of banks. A positive relationship is expected between network embeddedness and income diversification.

\section{Results and Discussion}

\subsection{Descriptive Statistics}

The result of the descriptive statistics of all the variables is presented in Table II, which shows that on average, income diversification is 0.67 . This is higher than the score of a little over 0.7 recorded in earlier studies such as Duho et al. (2020) and Duho and Onumah (2019). This can be explained by the fact that the current study used a larger dataset. Also, the z-score is 6.234 while credit risk is 0.031 over the study period. This suggests that the loan loss provisions cover about 3.1 percent of total loans and advances. The cash and cash equivalents represent 39.3 percent of all banks investigated over the period. Overall, the size of banks is 19.74 for all banks representing a nominal value of GH $\$ 1.01$ billion. This is relatively higher than what has been reported by earlier studies since the study covers 2017 which marks the start of the banking sector reform with a special focus on bank recapitalization. The proportion of deposits to total assets is 63.8 percent over the study period.

Table 2. Descriptive Statistics

\begin{tabular}{clcccc}
\hline Variable & Obs & Mean & Std.Dev. & Min & Max \\
\hline Idiv & 417 & 0.670 & 0.219 & -0.202 & 0.997 \\
Z-score & 418 & 6.234 & 5.206 & -8.199 & 38.493 \\
C-risk & 380 & 0.031 & 0.056 & -0.167 & 0.576 \\
Liquidity & 418 & 0.393 & 0.180 & 0.030 & 0.924 \\
Size & 418 & 19.735 & 1.652 & 13.692 & 22.981 \\
Network & 418 & 0.638 & 0.177 & 0.000 & 1.771 \\
\hline
\end{tabular}

Notes: Idiv, represents income diversification; Z-score, is a measure of bank stability; C-risk, represents credit risk which is lagged by one year; Liquidity, represents the liquidity risk of banks; Size, represents bank size; and Network represents the network embeddedness of banks. 


\subsection{Test for Multicollinearity}

The test of multicollinearity is important to ensure that independent variables are not correlated among themselves. The correlation analysis of the independent variables utilized in this study is presented in Table III. The results indicated that the highest correlation coefficient is 0.346 which is lower than the rule of thumb of 0.7 which was proposed by Kennedy (2008). In effect, the variables do not suffer from the curse of multicollinearity and could be used in the same model. A further variance inflation factor (VIF) test presents scores that are less than 10 which is argued by Wooldridge (2016) to be the highest level above which there is evidence of multicollinearity.

Table 3. Test for Multicollinearity

\begin{tabular}{ccccccc}
\hline Variables & VIF & $\mathbf{( 1 )}$ & $\mathbf{( 2 )}$ & $\mathbf{( 3 )}$ & $\mathbf{( 4 )}$ & $\mathbf{( 5 )}$ \\
\hline (1) Z-score & 1.08 & 1.000 & & & & \\
(2) C-risk & 1.15 & -0.008 & 1.000 & & & \\
(3) Liquidity & 1.16 & $0.255^{* * *}$ & $0.129^{* *}$ & 1.000 & & \\
(4) Size & 1.06 & 0.006 & -0.016 & $0.194^{* * *}$ & 1.000 & \\
(5) Network & 1.18 & $-0.196^{* * *}$ & $0.346^{* * *}$ & $0.100^{* *}$ & $0.111^{* *}$ & 1.000 \\
\hline
\end{tabular}

Notes: Z-score, is a measure of bank stability; C-risk, represents credit risk which is lagged by one year; Liquidity represents the liquidity risk of banks; Size represents bank size; Network, represents the network embeddedness of banks and $*, * *, * * *$ represent $10,5,1$ percent levels of significance respectively.

\subsection{Convergence of Income Diversification}

The results of both beta-convergence and sigma-convergence are reported in Table IV which are linked to Eqn. 1 and Eqn. 2. First of all, the results of Models 1 and 2 suggest that the beta-convergence of income diversification exists among Ghanaian banks. Specifically, $\beta$ is negative and significant at a 1 percent significant level with a rate of 76.3 percent. When the trend has been controlled for, the result remains negative and significant with a higher rate of 78.8 percent of beta-convergence. This result is similar to the beta-convergence evident in studies such as Fung (2006) Casu and Girardone (2010), Andrieş and Căpraru (2014) and Wild (2016) except that this study explores income diversification convergence which has not been explored in earlier studies. This means that for Ghanaian banks, less income diversified banks catch-up with the more income diversified counterparts over time. This can be motivated by advantages associated with diversification as banks in recent times aim to earn their income from multiple sources as the banking business model changes. The current knowledge economy provides a strong base for banks to change their business models to employ modern banking activities such as services, trading activities, and investment banking which do not form part of the traditional interest income of banks. As some banks make first-mover initiatives in using these technologies and services, others adopt the technologies and services and so increase their level of income diversification over time.

Secondly, while beta-convergence is necessary, it is not sufficient for sigma convergence since the catch-up effect of less diversified banks could be higher than the more diversified banks such that over time, beta-convergence will not exist as the former surpasses the latter. Again, there may be conditional convergence where banks converge towards different steady-states. Models 3 and 4 are used to test for the existence of sigma-convergence which aims to explore the cross-sectional disparity that could exist over time. The results reported in Model 3 and 4 show that $\beta$ is negative and statistically significant with a coefficient of 74 percent, suggesting that sigma-convergence exists among Ghanaian banks. When the year trend has been controlled for, the result records a higher rate of 74.5 percent. In effect, the disparity of income diversification of banks converges over time.

Overall, banks tend to adopt the technologies of their peers especially in the current business ecosystem of the knowledge economy. As intangible assets become the key strategic assets of banks, there is more tendency for less performing banks to adopt the technologies of best-performing banks. Besides, there is evidence of increasing levels of competition in Ghanaian banks over time as reported 
in earlier studies such as Alhassan and Ohene-Asare (2016) and Duho et al. (2020). Competition drives innovation and the quest to adopt best practices so it could be a key factor driving the convergence of income diversification among Ghanaian banks. Thirdly, there is a general tendency for convergence to be achieved when financial reforms are implemented while there will be divergence when there are shock or crisis moments. Banking sector reforms could play a key role in the convergence of income diversification of banks as reforms aim to encourage banks to adopt best practices.

Table 4. Regression Results on Convergence of Income Diversification

\begin{tabular}{|c|c|c|c|c|}
\hline & $\begin{array}{c}(1) \\
\Delta \mathrm{Idiv}\end{array}$ & $\begin{array}{c}(2) \\
\Delta \text { Idiv }\end{array}$ & $\begin{array}{l}\text { (3) } \\
\Delta \mathrm{D}\end{array}$ & $\begin{array}{l}(4) \\
\Delta \mathrm{D}\end{array}$ \\
\hline L.Idiv & $\begin{array}{c}-\mathbf{0 . 7 6 3} * * * \\
(0.051)\end{array}$ & $\begin{array}{c}-\mathbf{0 . 7 8 8} * * * \\
(0.050)\end{array}$ & & \\
\hline L.D & & & $\begin{array}{c}-\mathbf{0 . 7 4 0} * * * \\
(0.050)\end{array}$ & $\begin{array}{c}-\mathbf{0 . 7 4 5} \text { *** } \\
(0.050)\end{array}$ \\
\hline YEAR & & $\begin{array}{c}-\mathbf{0 . 0 0 8 * * *} \\
(0.002)\end{array}$ & & $\begin{array}{c}\mathbf{0 . 0 0 2} \\
(0.002)\end{array}$ \\
\hline _cons & $\begin{array}{c}\mathbf{0 . 5 2 0} * * * \\
(0.036)\end{array}$ & $\begin{array}{c}16.660^{* * *} \\
(4.058)\end{array}$ & $\begin{array}{c}\mathbf{0 . 0 0 9} \\
(0.008) \\
\end{array}$ & $\begin{array}{l}-4.838 \\
(3.874) \\
\end{array}$ \\
\hline Banks & 32 & 32 & 32 & 32 \\
\hline Obs. & 378 & 378 & 378 & 378 \\
\hline R-squared & 0.395 & 0.421 & 0.385 & 0.388 \\
\hline F-statistics & $224.85^{* * *}$ & $125.17^{* * *}$ & $215.79^{* * *}$ & $108.86^{* * *}$ \\
\hline
\end{tabular}

Notes: ${ }^{*},{ }^{* *},{ }^{* * *}$ represent $10,5,1$ percent levels of significance respectively.

\subsection{Determinants of Income Diversification}

The results of the determinants of income diversification among Ghanaian banks are reported in Table V. Three panel regression techniques namely panel corrected standard ordinary least squares (OLS-PCSE), fixed effects (FE) and systems generalized method of moments (S-GMM) are used to check the robustness of results. Generally, the models are statistically significant at 1 percent as depicted by the Wald $\chi 2$ test or F-statistics, which indicates the relevance of the explanatory variables. The OLS-PCSE regression accounts for heteroskedasticity, the FE accounts for all time-invariant differences in banks and the S-GMM result accounts for endogeneity. The test of instrument validity of the S-GMM estimation shows that there is no evidence of second-order serial correlation (Arellano \& Bond, 1991; Arellano \& Bover, 1995; Roodman, 2009).

The result shows that the lag of income diversification positively affects the income diversification of banks at statistically significant levels. This suggests that the level of diversification for the previous year affects the diversification strategy of the present year. In terms of z-score which is the measure of bank stability, the result shows a negative significant effect on income diversification for the OLS-PCSE estimation. This suggests that stable banks tend to be focused banks rather than diversified banks. This result agrees with the negative relationship evident in Meng et al. (2018) and Duho et al. (2020). Stiroh and Rumble (2006) posit that the gains from diversification do not offset the costs associated with increased risk exposure. In effect, stable banks may choose not to be more exposed to risk by diversification. In line with the result of this study, it is banks that are faced with high insolvency risk that diversify their operations.

Credit risk has a negative and significant effect on income diversification across all three estimation techniques. This suggests that as banks are exposed less to the risk of customers defaulting, they diversify into other income-generating businesses. Also, banks that are less exposed to credit risk diversify and those that are more exposed adopt a focused strategy. This means that banks are critical at considering their risk portfolio before diversifying which adds to their risk portfolio. Zhou (2014) argues that based on portfolio theory, banks could benefit from diversification in the form of risk reduction when they use innovative non-interest business. The interaction between z-score and credit 
risk has been explored with the result showing a positive and significant effect of the interaction variable on income diversification. This result indicates that although stable banks tend to adopt a focused strategy and banks avoid diversification to prevent the exposure of their risk portfolio to credit risk when it happens that stable banks are exposed to credit risk, they tend to adopt a diversification strategy. In effect, the credit risk stance of unstable banks differs from that of the stable banks and the choice of diversification may be driven by the level of exposure it gives to the risk portfolio of the banks.

Table 5. Regression Results on Determinants of Income Diversification

\begin{tabular}{|c|c|c|c|c|c|c|c|c|c|}
\hline & $\begin{array}{c}(1) \\
\text { OLS-PCSE }\end{array}$ & $\begin{array}{l}(2) \\
\text { FE }\end{array}$ & $\begin{array}{c}(3) \\
\text { S-GMM }\end{array}$ & $\begin{array}{c}(4) \\
\text { OLS-PCSE }\end{array}$ & $\begin{array}{l}(5) \\
\text { FE }\end{array}$ & $\begin{array}{c}(6) \\
\text { S-GMM }\end{array}$ & $\begin{array}{c}(7) \\
\text { OLS-PCSE }\end{array}$ & $\begin{array}{l}(8) \\
\text { FE }\end{array}$ & $\begin{array}{c}(9) \\
\text { S-GMM }\end{array}$ \\
\hline \multirow[t]{2}{*}{ L.DEP } & & & $0.280^{* * *}$ & & & $0.274^{* * *}$ & & & $0.234^{* *}$ \\
\hline & & & $(0.084)$ & & & $(0.084)$ & & & $(0.094)$ \\
\hline \multirow[t]{2}{*}{ Z-score } & $-0.004^{*}$ & 0.002 & -0.001 & $-0.007^{* * *}$ & 0.000 & -0.003 & $-0.005^{* *}$ & 0.001 & -0.002 \\
\hline & $(0.002)$ & $(0.002)$ & $(0.003)$ & $(0.002)$ & $(0.003)$ & $(0.003)$ & $(0.002)$ & $(0.002)$ & $(0.003)$ \\
\hline \multirow[t]{2}{*}{ C-risk } & $-0.556^{* * *}$ & $-0.374^{* *}$ & -0.353 & $-0.941^{* * *}$ & $-0.592^{* * *}$ & $-0.673^{* * *}$ & $-0.530^{* * *}$ & $-0.378^{* *}$ & $-0.366^{*}$ \\
\hline & $(0.189)$ & $(0.182)$ & $(0.223)$ & $(0.193)$ & $(0.221)$ & $(0.154)$ & $(0.180)$ & $(0.179)$ & $(0.212)$ \\
\hline \multirow[t]{2}{*}{ Z-score ${ }^{*}$ C-risk } & & & & $0.092^{* * *}$ & $0.047^{*}$ & $0.072^{* * *}$ & & & \\
\hline & & & & $(0.022)$ & $(0.027)$ & $(0.018)$ & & & \\
\hline \multirow[t]{2}{*}{ Liquidity } & $-0.246^{* * *}$ & $-0.200^{* * *}$ & $-0.179^{* *}$ & $-0.242^{* * *}$ & $-0.210^{* * *}$ & $-0.183^{* *}$ & $-0.217^{* * *}$ & $-0.140^{*}$ & $-0.167^{* *}$ \\
\hline & $(0.069)$ & $(0.074)$ & $(0.073)$ & $(0.067)$ & $(0.074)$ & $(0.072)$ & $(0.068)$ & $(0.075)$ & $(0.072)$ \\
\hline \multirow[t]{2}{*}{ Network } & $0.353^{* * *}$ & $0.200^{* * *}$ & $0.230^{* * *}$ & $0.330^{* * *}$ & $0.191^{* * *}$ & $0.214^{* * *}$ & $0.375^{* * *}$ & $0.204^{* * *}$ & $0.254^{* * *}$ \\
\hline & $(0.068)$ & $(0.070)$ & $(0.077)$ & $(0.068)$ & $(0.070)$ & $(0.079)$ & $(0.068)$ & $(0.069)$ & $(0.081)$ \\
\hline \multirow[t]{2}{*}{ Size } & -0.005 & $-0.016^{* *}$ & -0.007 & -0.007 & $-0.015^{* *}$ & -0.008 & $0.482^{* * *}$ & $0.415^{* * *}$ & $0.292^{*}$ \\
\hline & $(0.007)$ & $(0.007)$ & $(0.007)$ & $(0.006)$ & $(0.007)$ & $(0.007)$ & $(0.126)$ & $(0.130)$ & $(0.156)$ \\
\hline \multirow[t]{2}{*}{ Size $^{2}$} & & & & & & & $-0.012^{* * *}$ & $-0.011^{* * *}$ & $-0.010^{*}$ \\
\hline & & & & & & & $(0.003)$ & $(0.003)$ & $(0.004)$ \\
\hline \multirow[t]{2}{*}{ _cons } & $0.689^{* * *}$ & $0.941^{* * *}$ & $0.568^{* * *}$ & $0.762^{* * *}$ & $0.949^{* * *}$ & $0.615^{* * *}$ & $-4.037^{* * *}$ & $-3.244^{* *}$ & $-2.316^{* * *}$ \\
\hline & $(0.135)$ & $(0.149)$ & $(0.150)$ & $(0.128)$ & $(0.149)$ & $(0.147)$ & $(1.234)$ & $(1.264)$ & $(1.474)$ \\
\hline Wald $\chi^{2}$ & $43.85^{* * *}$ & & $44.57^{* * *}$ & $60.23^{* * *}$ & & $78.98^{* * *}$ & $62.63^{* * *}$ & & $67.64^{* * *}$ \\
\hline F-statistics & & $5.22^{* * *}$ & & & $4.86^{* * *}$ & & & $6.33^{* * *}$ & \\
\hline R-squared & 0.135 & & & 0.163 & & & 0.167 & & \\
\hline $\mathrm{AR}(1)$ & & & 0.000 & & & 0.000 & & & 0.000 \\
\hline $\mathrm{AR}(2)$ & & & 0.189 & & & 0.171 & & & 0.242 \\
\hline Hansen J test & & & 0.221 & & & 0.245 & & & 0.209 \\
\hline Instruments & & & 23 & & & 24 & & & 23 \\
\hline Banks & 32 & 32 & 32 & 32 & 32 & 32 & 32 & 32 & 32 \\
\hline Obs. & 379 & 379 & 378 & 379 & 379 & 378 & 379 & 379 & 378 \\
\hline
\end{tabular}

Notes: L.DEP represents the period lag of dependent variable; Idiv represents income diversification; Z-score is a measure of bank stability; $C$ - risk, represents credit risk which is lagged by one year; Z-score ${ }^{*}$-Risk is an interactive term; Liquidity, represents the liquidity risk of banks; Size represents bank size; Size $e^{2}$ is size squared; Network represents the network embeddedness of banks; $A R(1)$ - the first-order serial correlation; $A R(2)$ secondorder serial correlation; OLS-PCSE - panel corrected standard errors ordinary least squares; FE - fixed effects; $S$ GMM - system generalized method of moments; and ***,** represent 10, 5, 1 percent levels of significance, respectively.

The liquidity status of banks negatively affects income diversification at statistically significant levels. This implies that banks that have less cash and cash equivalent are those that diversify their income sources. This is mainly driven by the fact that these banks depend less on interest income sources such as treasury bills and rather invest in activities that are not interest related and obtain various fees and commissions from such activities. The network embeddedness of banks has a positive and significant effect on income diversification at a 1 percent level for all estimation methods. This is in line with earlier studies such as Sufian and Noor (2012), Sufian and Habibullah (2012) and Sufian 
(2009) suggesting that banks with the best network of actors, structures, systems, procedures, processes, and human capital tend to have the capacity needed to diversify. This is explained by the fact that customer relationship management is very key when banks aim to diversify their income sources. Essentially, the services, trading activities, investment banking, and consulting activities require a high level of customer engagement.

The effect of the size of banks on diversification seems to be different based on the variables at play. In the linear model and the interactive models, the effect of size on income diversification is negative and significant at 5 percent only in the fixed effect models. However, it is essential to explore the quadratic effect of size on income diversification. The results of this non-linear effect suggest that bank size has a positive and significant effect on income diversification for all three regression techniques which is in contrast with the negative relationship evident in Chiorazzo et al. (2008). This suggests that larger banks tend to be the leaders in the move towards income diversification. This is because they have various resources, technologies, human capital and innovative capital which enables them to utilize modern technologies to provide services to customers beyond the traditional business of intermediation. However, the benefits of diversification diminish as banks diversify. In effect, banks need to explore and know to what extent they can diversify so as not to make a net loss from diversification as a result of the risk-return trade-off.

\section{Conclusions}

The business of banking is a business of risk management. The traditional business of banking has a revenue model that is dependent on financial intermediation. However, in recent times, this has changed as banks explore other sources of income other than interest income sources. There is little knowledge of whether the strategy that banks adopt to earn income from non-traditional sources converge over time or among banks. Also, there is little knowledge of the determinants of income diversification among banks, especially in the emerging markets context. Using an unbalanced panel data of 32 Ghanaian banks covering the period 2000 to 2017, the study explores the determinants and convergence of income diversification.

The results of the study suggest that both beta-convergence and sigma-convergence exist among Ghanaian banks. This means that banks that are less diversified catch-up with the more diversified counterparts over time. This can be driven by the fact that competition in the industry is high, coupled with increasing roles of reforms in the sector. Also, the increase in the use of technology provides a basis for banks to imitate others by also engaging in non-interest generating activities of others. As beta-convergence indicates a catch-up effect, sigma-convergence indicates that over time, the disparity between the diversification strategy of banks would decline.

The results also indicate that the risk profile of banks affects their diversification strategy. Considering insolvency risk and credit risk, it is evident that banks that are faced with high insolvency risk tend to diversify while banks that are faced with low credit risk tend to diversify. First, this suggests that banks consider the type of risks they are exposed to in their choice to diversify. The result also indicates that for stable banks, they tend to adopt a diversification strategy even when they are exposed to credit risk. In terms of liquidity risk, diversified banks are more exposed as compared to focused banks. This is because they tend to keep lesser cash and cash equivalents as compared to focused banks which have to issue loan facilities to earn interest income. The network embeddedness of banks is a key factor that drives their motive to diversify as it provides them access to the various actors, processes, procedures, systems and human capital to carry out non-interest generating activities effectively. There is a curvilinear nexus between bank size and income diversification such that bigger banks increase the level of income diversification but do not do so when the risk-return trade-off does not favor them.

\section{Implications}

These results have essential implications for bank management, for policy and future research. Practice-wise, the study provides an insight into the fact that banks should not view their income 
diversification strategies as sacrosanct but should aim at enhancing them and improving upon them to make it more value relevant. While some banks could attempt to prevent their peers from copying or imitating their strategies, it is essential that it would be difficult to do this in the current business ecosystem of rapid change and technological improvement. The risk implications of the study are also very useful; bank managers need to consider their risk profile and risk portfolio when they wish to diversify. To adapt the diversification strategy of others, financial stability, credit risk exposure, and liquidity risk and network embeddedness should be considered. Bank managers need to also be aware that the size of the bank is key in decisions to diversify and that while large banks tend to diversify, at a point, this does not hold continually as at a point the net gains from diversification will deteriorate.

Policy-wise, the Bank of Ghana and the Securities and Exchange Commission will find the findings of the study useful. Similarly, it will be relevant to the newly established Financial Stability Council which has been established to identify and evaluate possible threats, vulnerabilities, and risks that undermine the stability of the financial sector. The result provides evidence of the fact that banks diversify based on their risk profile and their risk portfolio. Banking regulations should consider any abnormal changes in the norms among banks to ensure that they do not undermine the stability of banks or the sector. Future research could explore these concepts at a broader level such as in the African context or the global level. Another essential area of research is to examine what factors determine bank margins in Ghana. Studies can also test the loss leader hypothesis to examine whether or not banks engage in cross-pricing.

Author Contributions: Conceptualization, K.C.T.D., J.M.O. and E.T.A.; methodology, K.C.T.D.; software, K.C.T.D.; validation, K.C.T.D., J.M.O. and E.T.A; formal analysis, K.C.T.D.; resources K.C.T.D., J.M.O. and E.T.A; writing-original draft preparation, K.C.T.D.; writing-review and editing, K.C.T.D., J.M.O. and E.T.A. All authors have read and agreed to the published version of the manuscript.

Acknowledgments: We thank the Editor and the anonymous reviewers without any implications for their insightful feedback. We appreciate the efforts of Divine Mensah Duho during data collection.

Funding: This research received no external funding.

Conflicts of Interest: The authors declare no conflict of interest.

\section{References}

Abedifar, P., Molyneux, P., \& Tarazi, A. (2018). Non-interest Income and Bank Lending. Journal of Banking $\mathcal{E}$ Finance, 87, 411-426. doi:https://doi.org/10.1016/j.jbankfin.2017.11.003

Alhassan, A. L., \& Ohene-Asare, K. (2016). Competition and Bank Efficiency in Emerging Markets: Empirical Evidence from Ghana. African Journal of Economic and Management Studies, 7(2), 268-288. doi:https://doi.org/10.1108/ajems-01-2014-0007

Ammar, N., \& Boughrara, A. (2019). What drives the banks' diversification decision? A dynamic nonlinear panel data approach. Managerial and Decision Economics, 40(8), 907-922. doi:https://doi.org/10.1002/mde.3079

Andrieş, A. M., \& Căpraru, B. (2014). The Nexus Between Competition and Efficiency: The European Banking Industries Experience. International Business Review, 23(3), 566-579. doi:https://dx.doi.org/10.1016/j.ibusrev.2013.09.004

Arellano, M., \& Bond, S. (1991). Some Tests of Specification for Panel Data: Monte Carlo Evidence and an Application to Employment Equations. The review of economic studies, 58(2), 277-297. doi:https://doi.org/10.2307/2297968

Arellano, M., \& Bover, O. (1995). Another Look at the Instrumental Variable Estimation of Error-components Models. Journal of econometrics, 68(1), 29-51. doi:https://doi.org/10.1016/0304-4076(94)01642-d

Baele, L., De Jonghe, O., \& Vander Vennet, R. (2007). Does the Stock Market Value Bank Diversification? Journal of Banking \& Finance, 31(7), 1999-2023. doi:https://doi.org/10.1016/j.jbankfin.2006.08.003

Barro, R., \& Sala-i-Martin, X. (1991). Convergence Across States and Regions. Brookings papers on economic activity, 22(1), 107-182. doi:https://doi.org/10.2307/2534639

Barro, R. J. (1991). Economic Growth in a Cross-Section of Countries. The quarterly journal of economics, 106(2), 407443. doi:https://doi.org/10.2307/2937943 
Barro, R. J., \& Sala-i-Martin, X. (1992). Convergence. Journal of Political Economy, 100(2), $223-251$. doi:https://www.doi.org/10.1086/261816

Barth, J. R., Caprio, G., \& Levine, R. (2004). Bank Regulation and Supervision: What Works Best? Journal of Financial Intermediation, 13(2), 205-248. doi:https://doi.org/10.1016/j.jfi.2003.06.002

Boyd, J. H., Chang, C., \& Smith, B. D. (1998). Moral Hazard Under Commercial and Universal Banking. Journal of Money, Credit and Banking, 30(3), 426-468. doi:https://doi.org/10.2307/2601249

Casu, B., \& Girardone, C. (2010). Integration and Efficiency Convergence in EU Banking Markets. Omega, 38(5), 260-267. doi:https://doi.org/10.1016/j.omega.2009.08.004

Chiorazzo, V., Milani, C., \& Salvini, F. (2008). Income Diversification and Bank Performance: Evidence from Italian Banks. Journal of financial services research, 33(3), 181-203. doi:https://doi.org/10.1007/s10693-008-0029-4

Claessens, S., \& Klingebiel, D. (2001). Competition and Scope of Activities in Financial Services. The World Bank Research Observer, 16(1), 19-40. doi:https://doi.org/10.1093/wbro/16.1.19

DeYoung, R., \& Rice, T. (2004). Noninterest Income and Financial Performance at US Commercial Banks. Financial Review, 39(1), 101-127. doi:https://doi.org/10.1111/j.0732-8516.2004.00069.x

DeYoung, R., \& Roland, K. P. (2001). Product Mix and Earnings Volatility at Commercial Banks: Evidence from a Degree of Total Leverage Model. Journal of Financial Intermediation, 10(1), 54-84. doi:https://doi.org/10.1006/jfin.2000.0305

Duho, K. C. T., \& Onumah, J. M. (2019). Bank Diversification Strategy and Intellectual Capital in Ghana: An Empirical Evidence. Asian Journal of Accounting Research, 4(2), 246-259. doi:https://doi.org/10.1108/ajar-042019-0026

Duho, K. C. T., Onumah, J. M., \& Owodo, R. A. (2020). Bank Diversification and Performance in an Emerging Market. International Journal of Managerial Finance, 16(1), 120-138. doi:https://doi.org/10.1108/ijmf-04-20190137

Fung, M. K. (2006). Scale Economies, X-efficiency, and Convergence of Productivity Among Bank Holding $\begin{array}{lllll}\text { Companies. Journal of Banking } \mathcal{E} \quad \text { Finance, } & 30(10), & \text { 2857-2874. }\end{array}$ doi:https://dx.doi.org/10.1016/j.jbankfin.2005.11.004

Haubrich, J. G., \& Young, T. (2019). Trends in the Noninterest Income of Banks. Economic Commentary(2019-14). doi:http://dx.doi.org/10.26509/frbc-ec-201914

Hayden, E., Porath, D., \& Westernhagen, N. V. (2007). Does Diversification Improve the Performance of German banks? Evidence from Individual Bank Loan Portfolios. Journal of financial services research, 32(3), 123-140. doi:https://doi.org/10.1007/s10693-007-0017-0

John, K., John, T. A., \& Saunders, A. (1994). Universal Banking and Firm Risk-taking. Journal of Banking E Finance, 18(2), 307-323. doi:https://doi.org/10.1016/0378-4266(94)00037-9

Kennedy, P. (2008). A Guide to Econometrics (6th ed.). Oxford: Blackwell Publishing.

Laeven, L., \& Levine, R. (2007). Is there a Diversification Discount in Financial Conglomerates? Journal of Financial Economics, 85(2), 331-367. doi:https://doi.org/10.1016/0378-4266(94)00037-9

Lin, J.-R., Chung, H., Hsieh, M.-H., \& Wu, S. (2012). The Determinants of Interest Margins and their Effect on Bank Diversification: Evidence from Asian Banks. Journal of Financial Stability, 8(2), 96-106. doi:https://doi.org/10.1016/j.jfs.2011.08.001

Meng, X., Cavoli, T., \& Deng, X. (2018). Determinants of Income Diversification: Evidence from Chinese Banks. Applied Economics, 50(17), 1934-1951. doi:https://doi.org/10.1080/00036846.2017.1383594

Mercieca, S., Schaeck, K., \& Wolfe, S. (2007). Small European Banks: Benefits from Diversification? Journal of Banking E Finance, 31(7), 1975-1998. doi:https://doi.org/10.1016/j.jbankfin.2007.01.004

Pennathur, A. K., Subrahmanyam, V., \& Vishwasrao, S. (2012). Income Diversification and Risk: Does Ownership Matter? An Empirical Examination of Indian Banks. Journal of Banking E Finance, 36(8), 2203-2215. doi:https://doi.org/10.1016/j.jbankfin.2012.03.021

Roodman, D. (2009). How to do xtabond2: An Introduction to Difference and System GMM in Stata. The stata journal, 9(1), 86-136. doi:https://doi.org/10.1177/1536867X0900900106

Saunders, A. (1994). Banking and Commerce: An Overview of the Public Policy Issues. Journal of Banking E Finance, 18(2), 231-254. doi:https://doi.org/10.1016/0378-4266(94)00034-4

Solow, R. M. (1956). A Contribution to the Theory of Economic Growth. The quarterly journal of economics, 70(1), 65-94. doi:https://doi.org/10.2307/1884513 
Stiroh, K. J. (2004). Diversification in Banking: Is Noninterest Income the Answer? Journal of Money, Credit and Banking, 36(5), 853-882. doi:https://www.jstor.org/stable/3839138

Stiroh, K. J. (Ed.) (2007). Diversification in banking. Oxford: Oxford University Press.

Stiroh, K. J., \& Rumble, A. (2006). The Dark Side of Diversification: The Case of US Financial Holding Companies. Journal of Banking \& Finance, 30(8), 2131-2161. doi:https://doi.org/10.1016/j.jbankfin.2005.04.030

Sufian, F. (2009). Determinants of Bank Profitability in a Developing Economy: Empirical Evidence from the China Banking Sector. Journal of Asia-Pacific Business, 10(4), 281-307. doi:https://doi.org/10.1080/10599230903340205

Sufian, F., \& Habibullah, M. S. (2012). Globalizations and Bank Performance in China. Research in International Business and Finance, 26(2), 221-239. doi:https://doi.org/10.1016/j.ribaf.2011.12.005

Sufian, F., \& Noor, M. A. N. M. (2012). Determinants of Bank Performance in a Developing Economy: Does Bank Origins Matters? Global Business Review, 13(1), 1-23. doi:https://doi.org/10.1177/097215091101300101

Thota, N. (2019). Market Reaction to Banks Revenue Diversification Strategy: Evidence from India. Applied Economics Letters, 27(1), 25-29. doi:https://doi.org/10.1080/13504851.2019.1606400

Vithessonthi, C. (2016). Deflation, Bank Credit Growth, and Non-performing Loans: Evidence from Japan. International Review of Financial Analysis, 45, 295-305. doi:https://doi.org/10.1016/j.irfa.2016.04.003

Wild, J. (2016). Efficiency and Risk Convergence of Eurozone Financial Markets. Research in International Business and Finance, 36, 196-211. doi:https://doi.org/10.1016/j.ribaf.2015.09.015

Wooldridge, J. M. (2016). Introductory Econometrics: A Modern Approach (6th ed.). Boston: Cengage.

Zhang, J., Jiang, C., Qu, B., \& Wang, P. (2013). Market Concentration, Risk-taking, and Bank Performance: Evidence from Emerging Economies. International Review of Financial Analysis, 30(0), 149-157. doi:https://dx.doi.org/10.1016/j.irfa.2013.07.016

Zhou, K. (2014). The Effect of Income Diversification on Bank Risk: Evidence from China. Emerging Markets Finance and Trade, 50, 201-213. doi:https://doi.org/10.2753/REE1540-496X5003S312

(C) 2020 by the authors. This article is an open-access article distributed under the terms and conditions of the Creative Commons Attribution (CC BY) license (http://creativecommons.org/licenses/by/4.0/). 